\title{
HYPERBARIC OXYGEN THERAPY FOR SEVERE ULCERATIVE COLITIS REFRACTORY TO CONVENTIONAL THERAPIES. CASE REPORT
}

\author{
Ivaylo Vazharov \\ Clinic of Internal Diseases, Naval Hospital - Varna, Military Medical Academy
}

\begin{abstract}
Ulcerative colitis (UC) is a disease of unknown etiology characterized by inflammation of the mucosa and occasionally the submucosa of the colon. Conventional drug therapy for UC involves use of aminosalicylates (oral, topical, or both) for mild to moderate disease, corticosteroids, azathioprine/6-mercaptopurine, cyclosporine and anti-tumor necrosis factor therapy for a more severe disease. Those patients who do not respond to that therapy may require colectomy. In this article the successful use of hyperbaric oxygen therapy in the treatment of ulcerative colitis refractory to conventional therapies is described.
\end{abstract}

Keywords: hyperbaric oxygen therapy, ulcerative colitis

\section{INTRODUCTION}

Hyperbaric oxygen therapy (HBOT) provides $100 \%$ oxygen under pressure, which increases tissue oxygen levels, relieves hypoxia and alters inflammatory pathways. Hyperbaric oxygen therapy (HBOT) has been found to be safe and efficacious in the treatment of chronic wounds and inflammatory conditions, including inflammatory bowel disease (IBD) (1). According to the medical literature the evidence for a positive effect of HBOT is stronger for Crohn's disease than for ulcerative colitis (2). During treatment, the arterial $\mathrm{O}_{2}$ tension often exceeds $2000 \mathrm{mmHg}$ and levels of 200 to $400 \mathrm{mmHg}$ occur in tissues (3). Data from both the acetic acid and trinitrobenzesulphonic models of colitis in rats indicated

Address for correspondence:

Ivaylo Vazharov

Naval Hospital - Varna

Military Medical Academy, Bulgaria

3 Hr. Smirnenski St

Varna 9010

e-mail:vajarov@dir.bg

Received: December 23, 2016

Accepted: March 31, 2017 that the disease severity could be limited with HBOT (4).

\section{Case Presentation:}

The patient was a 30-year-old woman diagnosed with pan-colonic ulcerative colitis at the age of 23. She has had three previous hospitalizations for exacerbations of her disease, the most recent of which was 2 years prior. At the given moment she had 5 to 10 bowel movements daily, mixed with blood. She complained of general weakness, but did not have elevated temperature. Abdominal pain was minimal and was more centered in the lower portion. The patient had been taking 40 to $60 \mathrm{mg} / \mathrm{d}$ of prednisone over the previous 4 months, with inability to taper; she had taken $40 \mathrm{mg} / \mathrm{d}$ for the 3 weeks prior to hyperbaric therapy, which was continued during treatment. The patient had taken mesalazine (Salofalk $3 \mathrm{~g} / \mathrm{d}$ ) for several months as well. On physical examination there was minimal lower abdominal pain. From the examinations: Нв $90 \mathrm{~g} / \mathrm{l}$, ESR $45 \mathrm{~mm} / \mathrm{h}$, WBC $11 \times 10^{9}$. According to the Truelove-Witts score (5), as well as according to the Mayo score (6) the colitis was severe. Colonoscopy showed absent vascular lines, spontaneous bleeding and presence of ulcers in the rectum, the sigmoid, the descending and part of 
the transverse colon. By the Montreal Classification, UC is designated as E3 (7). Multiple biopsies from the colon showed marked distortion of glandular architecture, prominent lamina propria lymphoplasmacytic infiltrates and multifocal mucosal neutrophilic infiltrates forming numerous crypt abscesses. There was extensive mucosal ulceration.

The patient was given 15 courses (2-hour duration) of HBOT on a 5-day per week. The patient had a significant clinical improvement, she had 2 normal defecations daily and according to Truelove-Witts score the colitis was classified as mild. Colonoscopy showed mild-to-moderate ulcerative colitis. Histologic examination confirmed the clinical improvement. The hemoglobin level was $125 \mathrm{~g} / \mathrm{l}$, erythrocyte sedimentation rate $-14 \mathrm{~mm} / \mathrm{h}$., and white blood cell count - $7.5 \times 10^{9}$. The dose of corticosteroids was reduced by $10 \mathrm{mg}$ every week immediately after the final hyperbaric treatment until reaching $20 \mathrm{mg}$ daily and after that - by $5 \mathrm{mg}$ every week until the medicine was stopped. In 2 months clinical remission was achieved on the basis of the Truelove-Witts score. The patient remained on Salofalk - 3g/d. There was no recurrence of the disease in the next 4 months.

\section{DISCUSSION}

This clinical case showed the potential utility of HBOT in severe UC, refractory to conventional therapies. There are other reports in the literature concerning the positive effect of HBOT in the complex treatment of this disease. The mechanism of this effect is not known. HBOT has been shown to increase the oxygen content of plasma and body tissues and may normalize oxygen levels in ischemic tissues (8). Immunosuppressive effect due to reduction of $B$ and T lymphocytes in experimental models is presumed (9). HBOT also lowered pro-inflammatory cytokine concentrations and lowered biomarkers of inflammation and oxidative stress (10). Additional studies are warranted to investigate both the effects of HBOT on biomarkers of oxidative stress and inflammation as well as clinical outcomes in individuals with IBD.

\section{CONCLUSIONS}

HBOT has demonstrated efficacy and safety in the treatment of ulcerative colitis refractory to conventional therapies.

\section{REFERENCES}

1. Dulai PS, Gleeson MW, Taylor D, Holubar SD, Buckey JC, Siegel CA. Systematic review: The safety and efficacy of hyperbaric oxygen therapy for inflammatory bowel disease. Aliment Pharmacol Ther. 2014 Jun;39(11):1266-75.

2. Rossignol DA. Hyperbaric oxygen treatment for inflammatory bowel disease: a systematic review and analysis. Med Gas Res. 2012 Mar 15;2(1):6.

3. Thom SR. Hyperbaric oxygen: its mechanisms and efficacy. Plast Reconstr Surg. 2011 Jan;127 Suppl 1:131S-141S.

4. Rachmilewitz D, Karmeli F, Okon E, Rubenstein I, Better OS. Hyperbaric oxygen: a novel modality to ameliorate experimental colitis. Gut 1998;43:512-9.

5. Truelove SC, Witts LJ. Cortisone and corticotrophin in ulcerative colitis. Br Med J. 1959 Feb 14;1(5119):387-94.

6. Schroeder KW, Tremaine WJ, Ilstrup DM. Coated oral 5-aminosalicylic acid therapy for mildly to moderately active ulcerative colitis. A randomized study. N Engl J Med. 1987;317:1625-29.

7. Satsangi J, Silverberg MS, Vermeire S, Colombel JF. The Montreal classification of inflammatory bowel disease: controversies, consensus, and implications. - Gut, 55, 2006, № 6, 749-753.

8. Gill AL, Bell CN. Hyperbaric oxygen: its uses, mechanisms of action and outcomes. QJM. 2004;97(7):385-395.

9. Saito K, Tanaka Y, Ota T, Eto S, Yamashita U. Suppressive effect of hyperbaric oxygenation on immune responses of normal and autoimmune mice. Clin Exp Immunol. 1991 Nov;86(2):322-7.

10. Al-Waili NS, Butler GJ. Effects of hyperbaric oxygen on inflammatory response to wound and trauma: possible mechanism of action. ScientificWorldJournal. 2006;6:425-441. 